\title{
Reading Speed and Comprehension Enhancement in Hybrid Learning Delivery Mode
}

\author{
Muhaimin Abdullah*
}

State University of Makassar, Indonesia

Corresponding Author: Muhaimin Abdullah, E-mail: abdullahmuhaimin24@gmail.com

\section{ARTICLE INFO}

Article history

Received: January 14, 2018

Accepted: March 20, 2018

Published: June 30, 2018

Volume: 9 Issue: 3

Advance access: May 2018

Conflicts of interest: None

Funding: None

\section{Key words:}

Hybrid Learning,

Blended Learning,

Web-based Reading,

Reading Speed,

Reading Comprehension

\begin{abstract}
The main objective of this research is to find out whether rate-buildup reading, skimming, and scanning strategies applied in hybrid learning method help students boost their reading speed and comprehension. This research employed quasi-experimental design. 15 students were involved into experimental group and 15 were enrolled into control group. Students of experimental group were treated through hybrid learning delivery mode in which web-based portal accessible on www.muhaiminabdullah.com was hosted as reading portal while students of control group were assigned only to paper-based reading activities in face-to-face method of contents delivery. Both students of experimental group and students of control group successfully boost their reading speed and comprehension. It is implied that reading speed and comprehension are possible to be enhanced both in web-based reading portal and in face to face. The dispersion of standard deviation on posttest that tends to be high suggests that further researchers conduct the experiment in a more well-controlled design towards experimental group.
\end{abstract}

\section{INTRODUCTION}

Issue on reading rates in college students had been discussed since $20^{\text {th }}$ century. In terms of rapid and effective reading, Pauk and Smith agree that speed reading is useless (O'Reilly $\&$ Walker, 1989). Furthermore, the study also claims that unrealistic speed reading attainment (e.g. 1,000 wpm) is commonly suggested in literatures. Prior to this study, a 1952 publication that examines 3 drills given in three months with various speed reading tests such as 400,600, or 1,000 words per-minute (wpm) as well as various level of texts wisely reveals that reading speed depends on the students themselves, vocabulary contained in the text, and implicitly reveals that it depends on how importance the text for the students as indicated by a student who speeds up when the stuff is not important and slows down when it is (Andrews, 1952, p. 356).

The researcher hypothesized that by considering the rapid advancement of information and technology nowadays, such artificial method to speed reading and comprehension might be possible to be reached. Abundant publications have revealed positive effects of the integration information and technology in English as second/foreign language learning. A 2012 study reports that Facebook promotes grammar learning for EFL students and the students' attitude are found positive (Baturay, Daloglu, \& Yildirim, 2010; Suthiwartnarueput \& Wasanasomsithi, 2012). The previous claim is supported by some studies that claim internet technologies (which commonly refers to as web 2.0 technology) have been embraced by educators in teaching and learning (Ho, 2013) and result to positive effects on students (Chen \& Huang, 2014; Dogoriti, Pange, \& S. Anderson, 2014; Gözde Girgin, 2011; Laire, Casteleyn, \& Mottart, 2012; Özdemir, 2017; Sun \& Yang, 2013).

For writing purposes, the use of weblog is reported positive towards EFL learners' cognitive, affective, and psychomotor (Amir, Ismail, \& Hussin, 2011; Arslan \& Şahin-Kız1l, 2010; Mahmoudi, Samad, \& Razak, 2012; Vurdien, 2013) and promotes intercultural learning (García-Sánchez \& Rojas-Lizana, 2012). Another technology which is reported positive for English as second/foreign language learning purposes is wiki (Chao \& Lo, 2011; Kessler \& Bikowski, 2010; Li \& Zhu, 2013; Zou, Wang, \& Xing, 2015). For speaking purposes, the use of weblog is also examined and the findings fall into positive conclusion (Huang, 2013; Hung \& Huang, 2015) so does for reading (Yakut \& Aydın, 2015).

Based on previous claims, conclusion that can be drawn is that Web 2.0 technology has great potential to be utilized as a medium for language learning purposes. However, besides positive effects offered by information and technology, negative effects are also found. One negative effect of technology-based learning was reported in a 2012 study. 
The study reveals that e-learning creates a sense of isolation among students and also lead to a pause in learner-instructor interaction. Furthermore, it is revealed that students look too busy with their laptop (Saglam \& Sert, 2012).

The implementation of e-learning, as the umbrella of technology-integrated learning, has both advantages and disadvantages when it is integrated into education. Through this research study, the researcher tries to maximize the advantages and to minimize the disadvantages of the implementation of e-learning in education through hybrid learning delivery mode. Hybrid learning itself by is simply defined as face-to-face teaching and learning mixed with electronic learning approach (Grgurović, 2011).

Both advantages and disadvantages have been reported by many researchers related to the implementation of hybrid learning method for educational purposes. Nevertheless, very little has been reported about its implementation in reading classroom, especially its contribution in boosting students' reading speed and comprehension. Furthermore, through this research study, the researcher attempted to verify whether or not the implementation of hybrid learning method boosts students' reading speed and comprehension.

\section{REVIEW OF RELATED LITERATURE}

In this $21^{\text {st }}$ century, it is commonly known that electronic text has replaced the application of paper-based text (Rose, 2011). A study claims that in both normal and fast reading speed activity, details are less well recalled than more general information. Furthermore, comprehension is found reduced in fast reading (M. Dyson \& Haselgrove, 2000, p. 219). However, comprehension is not dependent on speed (M. C. Dyson \& Haselgrove, 2001) as indicated in a study that finds no significant difference between groups in reading speed or the level of comprehension in paper-based and on-screen reading (Dündar \& Akçayır, 2017). In response to the previous phenomenon, various reading techniques as well as reading activities such as repeated reading, timed-reading, rate-buildup reading, the use of pacer, skimming, and scanning are suggested (Anderson, 1999; Buzan, 2003; Cutler, 1993; Snow, 2002; Wainwright, 2007).

It is hypothesized in Weber's inventory that case, size, type, and color of font used in a text and predetermined order of text provide more stimulation to the right brain which deals with visual processing (Weber, 2002). Still in Weber's inventory, text readability is also hinted as a supporting factor to reading speed and comprehension. In a more recent study that carries a theme called 'reading smarter not faster', it is concluded that speed reading is not recommended. Furthermore, it is explained that speed reading is specified for determining the relevancy between text and particular topic. The researchers suggest reading retention for meaning acquisition (Thielen, Grochowski, \& Perpich, 2016, p. 329).

In line with previous statement, research result issued a decade before $21^{\text {st }}$ century claims that efforts to train readers at speeds well in excess of 400 wpm should now be considered professionally indefensible (O'Reilly \& Walker, 1989, p. 10). In contrast, students' involvement into drills offers improvement towards speed reading and comprehension. Vocabulary, level of the text, and the importance of the text for the students influence the improvement. It is explained that potentialities are almost limitless, and that student will improve by learning consciously to adjust the speed of his reading to his materials and his objectives (Andrews, 1952). A 2014 study about speed reading improvement in a speed reading course and its effect on language memory span found that reading speed improvement in a speed reading course did not necessarily negatively affect comprehension (Tran \& Nation, 2014). When different media that display text or passage are to be compared, paper, computers, and e-readers do not differently affect comprehension especially in narrative or expository text (Margolin et al., 2013).

When assessing potentials offered by technology nowadays, study that investigates approach in structuring arrangements of hybrid learning explains that the integration of electronic learning (e-learning) with classical classroom instruction fosters some highly desirable developments, such as more individualized and flexible learning (Bärenfänger, 2005). Furthermore, hybrid of face-to-face and CALL (computer assisted language learning) is highly suggested for effectiveness since technology in classroom means supplementary tool for learning - not to replace educators' presence in classroom (Ayres, 2002; Noni, 2004).

A 2008 study gauged students' attitude toward the use of computer-assisted language learning using website as media for online learning found that learning website helps the students in boosting their confidence and interest in learning English. Furthermore, using the website results not only on linguistic skills improvement, but also has positive impact on motivation (Hsu \& Sheu, 2017). When technology is combined with classical classroom or face-to-face teaching method (commonly known as hybrid learning), it is found that both ease of use and perceived usefulness have a positive effect on attitude (Tselios et al., 2011). Moodle, the most widely used platform in hybrid learning method (Yeou, 2016) is considered as an ideal platform for on-line courses and classes as well as a complement for on-sites classes. Furthermore, Moodle is stated as a tool that promotes communication in a global manner, by means of interaction of the four linguistic skills and by means of cooperation (Etxebarria et al., 2012).

\section{METHODOLOGY}

This research applied quasi-experimental design. In experimental study, the researcher selected the groups, decided what treatment will go to which group, controlled extraneous variables, and measured the effect of the treatment (Gay et al., 2006). Pretest and posttest were given to both experimental group and control group. In collecting the data, the researcher applied two instruments namely reading speed test and reading comprehension test. Reading speed test was applied to measure students' actual reading speed while reading comprehension test was applied to track students' comprehension towards the text the students read. Speed and comprehension enhancements were two variables measured in this quasi-experimental research.

Flesch Reading Ease was applied in order to determine the readability of the passage used in pretest, treatment, and posttest. For passage used in pretest and posttest, the Flesch 
Reading Ease score was 54.4 (fairly difficult). The following formula was used.

$\mathrm{RE}=206.835-(1.015 \times \mathrm{xASL})-(84.6 \mathrm{xASW})$

Wherein:

RE : Reading Ease

ASL : Average Sentence Length

AWS : Average number of syllables per word

With regard to reading speed classroom exercises, the researcher adopted some techniques suggested by experts such as the application of pacer, skimming, and scanning (Buzan, 2003; Cutler, 1993; Konstant, 2010; Wainwright, 2007) in classroom activities such as rate-buildup reading or timed-reading and repeated reading (Anderson, 1999).

In conducting the research, both students of experimental group and students of control group were assigned into six reading speed and comprehension phases. They were required to read one passage three times each meeting. Each passage was read by applied three different reading activities. The first was rate-buildup reading followed by answering comprehension questions; the second was rate-buildup reading, answering comprehension questions with opportunity to look back toward the passage while answering comprehension questions; and the third was rate-buildup reading followed by skimming and scanning.

The students of experimental group were treated through hybrid learning method; in this case, a web-based portal accessible on www.muhaiminabdullah.com was used as a medium in delivering the passages and instructions. For the online platform, learning management system (LMS) Moodle was modified by the researcher by adding some additional features for speed reading such as timed-reading module which was intended to obtain time that the students spent in reading and answering the comprehension questions. That method of delivery was combined with face-to-face method to meet the requirement of hybrid or blended learning approach. Different treatment was applied for students of control group; in this case, they were involved in paper-based reading method in which they were given printed passages with comprehension questions.

In scoring students' reading speed, the researcher applied scoring technique by respectively subtracting students' starting time with finishing time; converting the whole minutes into seconds by multiplying by 60 ; adding any extra seconds; dividing total seconds with the number of words of reading passage. It represented the words-per-second (wps) rate. The result was then multiplied by 60 to obtain words-per-minute (wpm) rate (Buzan, 2003, p. 26; Cutler, 1993; Konstant, 2010, p. 25; Wainwright, 2007, p. 34).

Therefore, the classification of reading speed is shown on table 1 .

After reading the passage, both students of experimental group and students of control group were required to answer comprehension questions. Therefore, the following formula was used.

\section{$\frac{\text { Students correct answer }}{\text { Total number of items }} \times 100$}

Students' comprehension scores were classified based on table 2 as shown below.
Table 1. The classification of reading speed

\begin{tabular}{lcl}
\hline No. & Reading speed $(\mathbf{w p m})$ & Classification \\
\hline 1. & $0-150$ & Poor \\
2. & $150-300$ & Average \\
3. & $300-500$ & Good \\
4. & $500-750$ & Excellent \\
5. & $750-1000$ & Unbelievable \\
\hline
\end{tabular}

Table 2. The classification of comprehension score

\begin{tabular}{lcl}
\hline No. & Comprehension score & Classification \\
\hline 1. & $81-100$ & Excellent \\
2. & $61-80$ & Good \\
3. & $41-60$ & Fair \\
4. & $21-40$ & Poor \\
5. & $0-20$ & Very Poor \\
\hline
\end{tabular}

\section{RESULTS}

\section{Reading Speed}

In both pretest and posttest, both students of experimental group and students of control group were assigned into reading speed test. The rate percentage of students' reading speed in pretest and posttest is shown in table 3 .

Table 3 shows that most of the participants including students involved into experimental group and students of control group are in the same category in pretest. The data represent homogeneity in terms of reading speed and comprehension.

In posttest, both students of experimental group and students of control group were assigned into reading speed test as they did in pretest. Table 3 shows that students involved in experimental group gain higher rate in reading speed than students involved into control group. In posttest, 10 students of experimental group (67\%) classified into Good and 5 students of experimental group (33\%) classified into Average. For control group, 2 students (13\%) classified as Good, 9 students $(60 \%)$ classified as Average, and 4 students (27\%) classified as Poor.

Furthermore, the mean score and standard deviation of students reading speed in pretest and posttest are shown in the following Table 4:

Table 4 shows different mean score of experimental group and control group. Before the experimentation, the mean score in pretest of experimental group and control group show the higher different score of mean score.

\section{Reading Comprehension}

Table 5 below draws results obtained in pretest and posttest regarding students reading comprehension.

Scores in pretest in both groups shows that most of the students are in the very poor, poor, fair, and good category. In the experimental group, $3(20 \%)$ students are in very poor category, $5(33 \%)$ students are in poor category, $4(27 \%)$ students are in fair category, and $3(20 \%)$ students are in good 
Table 3. The mean score and standard deviation of students' reading speed in pretest and posttest

\begin{tabular}{|c|c|c|c|c|c|c|c|c|c|c|}
\hline \multirow[t]{3}{*}{ No. } & \multirow[t]{3}{*}{ wpm } & \multirow[t]{3}{*}{ Classification } & \multicolumn{4}{|c|}{ Experimental group } & \multicolumn{4}{|c|}{ Control group } \\
\hline & & & \multicolumn{2}{|c|}{ Pretest } & \multicolumn{2}{|c|}{ Posttest } & \multicolumn{2}{|c|}{ Pretest } & \multicolumn{2}{|c|}{ Posttest } \\
\hline & & & $\mathbf{F}$ & $\%$ & $\mathbf{F}$ & $\%$ & $\mathbf{F}$ & $\%$ & $\mathbf{F}$ & $\%$ \\
\hline 1. & $0-150$ & Poor & 0 & 0 & 0 & 0 & 4 & 27 & 4 & 27 \\
\hline 2. & $150-300$ & Average & 14 & 93 & 5 & 33 & 11 & 73 & 9 & 60 \\
\hline 3. & $300-500$ & Good & 1 & 7 & 10 & 67 & 0 & 0 & 2 & 13 \\
\hline 4. & $500-750$ & Excellent & 0 & 0 & 0 & 0 & 0 & 0 & 0 & 0 \\
\hline \multirow[t]{2}{*}{5.} & $750-1000$ & Unbelievable & 0 & 0 & 0 & 0 & 0 & 0 & 0 & 0 \\
\hline & & Total & 15 & 100 & 15 & 100 & 15 & 100 & 15 & 100 \\
\hline
\end{tabular}

Table 4. The mean score and standard deviation of students' reading speed in pretest and posttest

\begin{tabular}{lcccc}
\hline Group statistics & & & & \\
\hline Group & N & Mean & Standard deviation & Standard error mean \\
\hline Pretest & & & & \\
$\quad$ Experimental & 15 & 194.00 & 50.941 & 13.153 \\
Control & 15 & 177.07 & 26.437 & 6.826 \\
Posttest & & & 13.689 \\
$\quad$ Experimental & 15 & 308.53 & 53.017 & 14.312 \\
Control & 15 & 180.00 & 55.428 & \\
\hline
\end{tabular}

Table 5. The mean score and standard deviation of students' comprehension in pretest and posttest

\begin{tabular}{|c|c|c|c|c|c|c|c|c|c|c|}
\hline \multirow[t]{3}{*}{ No. } & \multirow[t]{3}{*}{ Score } & \multirow[t]{3}{*}{ Classification } & \multicolumn{4}{|c|}{ Experimental group } & \multicolumn{4}{|c|}{ Control group } \\
\hline & & & \multicolumn{2}{|c|}{ Pretest } & \multicolumn{2}{|c|}{ Posttest } & \multicolumn{2}{|c|}{ Pretest } & \multicolumn{2}{|c|}{ Posttest } \\
\hline & & & $\mathbf{F}$ & $\%$ & $\mathbf{F}$ & $\%$ & $\mathbf{F}$ & $\%$ & $\mathbf{F}$ & $\%$ \\
\hline 1. & $81-100$ & Very Good & 0 & 0 & 4 & 27 & 0 & 0 & 0 & 0 \\
\hline 2. & $61-80$ & Good & 3 & 20 & 6 & 40 & 0 & 0 & 4 & 27 \\
\hline 3. & $41-60$ & Fair & 4 & 27 & 4 & 27 & 8 & 53 & 5 & 33 \\
\hline 4. & $21-40$ & Poor & 5 & 33 & 1 & 7 & 4 & 27 & 5 & 33 \\
\hline \multirow[t]{2}{*}{5.} & $0-65$ & Very Poor & 3 & 20 & 0 & 0 & 3 & 20 & 1 & 7 \\
\hline & & Total & 15 & 100 & 15 & 100 & 15 & 100 & 15 & 100 \\
\hline
\end{tabular}

category. In control group, $3(20 \%)$ students are in very poor category, 4 (27\%) students are in poor category, and 8 (53\%) students are in fair category. The data indicates homogeneity in terms of comprehension conducted in pretest.

In posttest, the data shows that in experimental group, $1(7 \%)$ student is classified as poor, $4(27 \%)$ students are in fair classification, $6(40 \%)$ students are in good classification, and $4(27 \%)$ students are in very good classification. In control group, $1(7 \%)$ student is in very poor classification, $5(33 \%)$ students are in poor classification, $5(33 \%)$ students are in fair classification, and $4(27 \%)$ students are in good classification. The data from posttest indicate that students in experimental group recall more than students in control group.

The following is the mean score and standard deviation of students' comprehension in pretest and posttest.

Table 6 shows different mean score of experimental group and control group. After conducting the experimentation, the score of the posttest of both experimental group and control group show the higher different score of mean score.

\section{Test of Significance}

The hypotheses were tested by using inferential statistic using SPSS Version 18.0. Test of significance (t-test) was used by the researcher for independent sample test. It was intended to know the significance different between the result of the students' mean score in the pretest and posttest both in experimental group and control group. Table 7 below describes the probability value of t-test of both groups in reading speed test.

Table 7 shows that the probability value or p-value is higher than the level of significance $(.26>.05)$ where the degree of freedom (df) is 28. It is assumed that the null hypothesis $(\mathrm{H} 0)$ is accepted and the alternative hypothesis $(\mathrm{H} 1)$ is rejected. Furthermore, it can be interpreted that there is no significance difference between the students' reading speed both in experimental group and control group before treatment.

Whereas, the data on posttest of the experimental group and the control group show that the probability 
Table 6. The mean score and standard deviation of students' comprehension in pretest and posttest

\begin{tabular}{lcccc}
\hline Group statistics & & & & \\
\hline Group & N & Mean & Standard deviation & Standard error mean \\
\hline Pretest & & & & \\
$\quad$ Experimental & 15 & 48.00 & 23.664 & 6.110 \\
Control & 15 & 46.67 & 16.330 & 4.216 \\
Posttest & & & 4.727 \\
Experimental & 15 & 77.33 & 18.310 & 4.860 \\
Control & 15 & 56.00 & 18.822 & \\
\hline
\end{tabular}

Table 7. The probability value of t-test of the experimental group and control group in reading speed test

\begin{tabular}{|c|c|c|c|c|c|c|c|c|c|}
\hline \multicolumn{10}{|c|}{ Independent samples test } \\
\hline & \multicolumn{2}{|c|}{$\begin{array}{l}\text { Levene's test } \\
\text { for equality } \\
\text { of variances }\end{array}$} & \multicolumn{7}{|c|}{ t-test for equality of means } \\
\hline & \multirow[t]{2}{*}{$\mathbf{F}$} & \multirow[t]{2}{*}{ Sig. } & \multirow[t]{2}{*}{$\mathbf{t}$} & \multirow[t]{2}{*}{ df } & \multirow[t]{2}{*}{$\begin{array}{c}\text { Sig. } \\
\text { (2-tailed) }\end{array}$} & \multirow[t]{2}{*}{$\begin{array}{c}\text { Mean } \\
\text { difference }\end{array}$} & \multirow{2}{*}{$\begin{array}{l}\text { Standard } \\
\text { error } \\
\text { difference }\end{array}$} & \multicolumn{2}{|c|}{$\begin{array}{l}95 \% \text { Confidence interval of } \\
\text { the difference }\end{array}$} \\
\hline & & & & & & & & Lower & Upper \\
\hline \multicolumn{10}{|l|}{ Pretest } \\
\hline $\begin{array}{l}\text { Equal variances } \\
\text { assumed }\end{array}$ & 3.659 & 0.066 & 1.143 & 28 & 0.26 & 16.933 & 14.819 & -13.421 & 47.288 \\
\hline $\begin{array}{l}\text { Equal variances } \\
\text { not assumed }\end{array}$ & & & 1.143 & 21.031 & 0.26 & 16.933 & 14.819 & -13.881 & 47.748 \\
\hline \multicolumn{10}{|l|}{ Posttest } \\
\hline $\begin{array}{l}\text { Equal variances } \\
\text { assumed }\end{array}$ & 0.033 & 0.857 & 6.490 & 28 & 0.00 & 128.533 & 19.804 & 87.966 & 169.100 \\
\hline $\begin{array}{l}\text { Equal variances } \\
\text { not assumed }\end{array}$ & & & 6.490 & 27.945 & 0.00 & 128.533 & 19.804 & 87.963 & 169.104 \\
\hline
\end{tabular}

value (p-value) is lower than level of significance; that is $.00<.05$. It indicates that there is significance different between the students' reading speed and comprehension in experimental group and control group after the treatment. The significance of t-test can be seen in the following table.

Table 9 below illustrates the probability value of t-test of both groups in comprehension test.

Table 9 shows that the probability value or p-value is higher than the level of significance $(.859>.05)$ where the degree of freedom (df) is 28 . It is assumed that the null hypothesis $(\mathrm{H} 0)$ is accepted and the alternative hypothesis $(\mathrm{H} 1)$ is rejected. Furthermore, it can be interpreted that there is no significance difference between the students' comprehension both in experimental group and control group before treatment.

Whereas, the data on posttest of the experimental group and the control group show that the probability value (p-value) is lower than level of significance; that is.004 <.05. It indicates that there is significance different between the students' reading speed and comprehension in experimental group and control group after the treatment. The significance of t-test can be seen in the following table.

\section{DISCUSSION}

The description of collected data displayed previously shows the enhancement of students' reading speed that is directly proportional to students' comprehension. Results of this research confirm previous findings that fall into conclusion that comprehension is not influenced by media - such as paper, computers, and e-readers - where text or passage is presented (Margolin et al., 2013, p. 518). In other words, digital media support and promote reading for understanding. In its relation to reading speed, results of this research also support claim that information recalled in reading through web is not dependent on speed (M. C. Dyson \& Haselgrove, 2001), that people with experience reading on screen have increased their level of reading speed and comprehension (M. Dyson \& Haselgrove, 2000). Similar results are in-line with findings that find no significant difference between groups in reading speed or the level of comprehension in paper-based reading and on-screen reading (Dündar \& Akçayır, 2017). In addition, results of this research also support claim that reading speed does not negatively affect comprehension (Tran \& Nation, 2014). These claims confirm that reading speed and comprehension are united as one element in reading process (Wainwright, 2007, p. 34). 
Table 8. The significance difference

\begin{tabular}{lccl}
\hline Variables & P-value & $(\alpha)$ & Remarks \\
\hline Pretest of experimental and control groups & 0.26 & 0.05 & Not significantly different \\
Posttest of experimental and control groups & 0.00 & 0.05 & Significantly different \\
\hline
\end{tabular}

Table 9. The probability value of t-test of the experimental group and control group in comprehension test

\begin{tabular}{|c|c|c|c|c|c|c|c|c|c|}
\hline \multicolumn{10}{|c|}{ Independent samples test } \\
\hline & \multicolumn{2}{|c|}{$\begin{array}{l}\text { Levene's test } \\
\text { for equality of } \\
\text { variances }\end{array}$} & \multicolumn{7}{|c|}{ t-test for equality of means } \\
\hline & \multirow[t]{2}{*}{$\mathbf{F}$} & \multirow[t]{2}{*}{ Sig. } & \multirow[t]{2}{*}{$\mathbf{t}$} & \multirow[t]{2}{*}{ df } & \multirow[t]{2}{*}{$\begin{array}{c}\text { Sig. } \\
\text { (2-tailed) }\end{array}$} & \multirow[t]{2}{*}{ Mean difference } & \multirow[t]{2}{*}{$\begin{array}{l}\text { Stadard } \\
\text { error } \\
\text { difference }\end{array}$} & \multicolumn{2}{|c|}{$\begin{array}{c}95 \% \text { Confidence } \\
\text { ionterval of the } \\
\text { difference }\end{array}$} \\
\hline & & & & & & & & Lower & Upper \\
\hline \multicolumn{10}{|l|}{ Pretest } \\
\hline $\begin{array}{l}\text { Equal variances } \\
\text { assumed }\end{array}$ & 1729 & 0199 & 0180 & 28 & 0859 & 1.333 & 7.424 & -13.873 & 16.540 \\
\hline $\begin{array}{l}\text { Equal variances } \\
\text { not assumed }\end{array}$ & & & 0180 & 24.869 & 0859 & 1.333 & 7.424 & -13.960 & 16.627 \\
\hline Posttest & & . & & & & & & & \\
\hline $\begin{array}{l}\text { Equal variances } \\
\text { assumed }\end{array}$ & 0107 & 0746 & 3.147 & 28 & 0004 & 21.333 & 6.780 & 7.445 & 35.222 \\
\hline $\begin{array}{l}\text { Equal variances } \\
\text { not assumed }\end{array}$ & & & 3.147 & 27.979 & 0004 & 21.333 & 6.780 & 7.445 & 35.222 \\
\hline
\end{tabular}

Point to be emphasized is that rate-buildup reading, skimming, and scanning strategies are possible to be practiced in on-screen reading activity. That case, size, color, and text readability influence reading speed and comprehension (Weber, 2002) is in line with the results of this research since the author modifies the learning management system Moodle by considering font case, size, as well as color. However, suggestion that speed reading is not recommended (Thielen et al., 2016) might depend on the (i) objectives of the reading - as indicated by participants in a 1952 study that narrates a student speeds up when the stuff is not important and slow down when it is; and (ii) suggestion given to the students - as narrated that a student can read fast and slow depends on what the students are told to do (Andrews, 1952 , p. 356). Besides, previous studies claim that comprehension does not influenced by speed in reading (Tran \& Nation, 2014). It can be concluded that comprehension depends not only on speed but focus, purposes, and range of concentration matter.

Regarding method of delivery, countless research studies have explicitly proven that hybrid learning or also known as blended learning effective to be implemented in language learning. This study verifies that hybrid learning approach, reading strategies, and reading activities applied in this experimental research promote the enhancement of speed reading and comprehension. Improvement in terms of reading speed and comprehension is possible to be made through hybrid learning as indicated in research study that fall into conclusion that hybrid learning fosters some highly desirable developments (Bärenfänger, 2005).
Regarding the results of this research, an important note drawn is that standard deviation in pretest of experimental group - in both reading speed and reading comprehension tests - tends to be high. Dispersion found in standard deviation of experimental group in pretest indicates that heterogeneity may exist in terms of reading speed and comprehension in pretest. If it is compared to mean scores as illustrated in Table 3 and Table 5, points scored by students of experimental group in pretest are relatively the same. Then, it can simply be interpreted as a weakness in handling the pretest particularly for experimental group in both reading speed test and reading comprehension test.

Since extraneous variable in quantitative experiment is unavoidable, the extraneous variables such as participant variables and situational variables may transform to confounding variables that influence the score in pretest. The researcher admits that such extraneous variables that become confounding variables influence the internal validity - distorting the influence of rate-buildup reading, skimming, and scanning conducted in hybrid learning approach towards the enhancement of reading speed and comprehension - of this experiment.

In general, the relationship between reading speed and comprehension is coincided as illustrated in Figure 1.

Figure 1 illustrates four main characteristics of students in reading and comprehending the passage. However, reading with comprehension will never be out of those four boxes. Hybrid learning method applied when conducting this research proves that students' reading speed and comprehension are possible to be boosted by adopting appropriate 
Table 10. The significance difference

\begin{tabular}{llll}
\hline Variables & P-value & $(\boldsymbol{\alpha})$ & Remarks \\
\hline Pretest of experimental and control groups & 0.859 & 0.05 & Not significantly different \\
Posttest of experimental and control groups & 0.004 & 0.05 & Significantly different \\
\hline
\end{tabular}

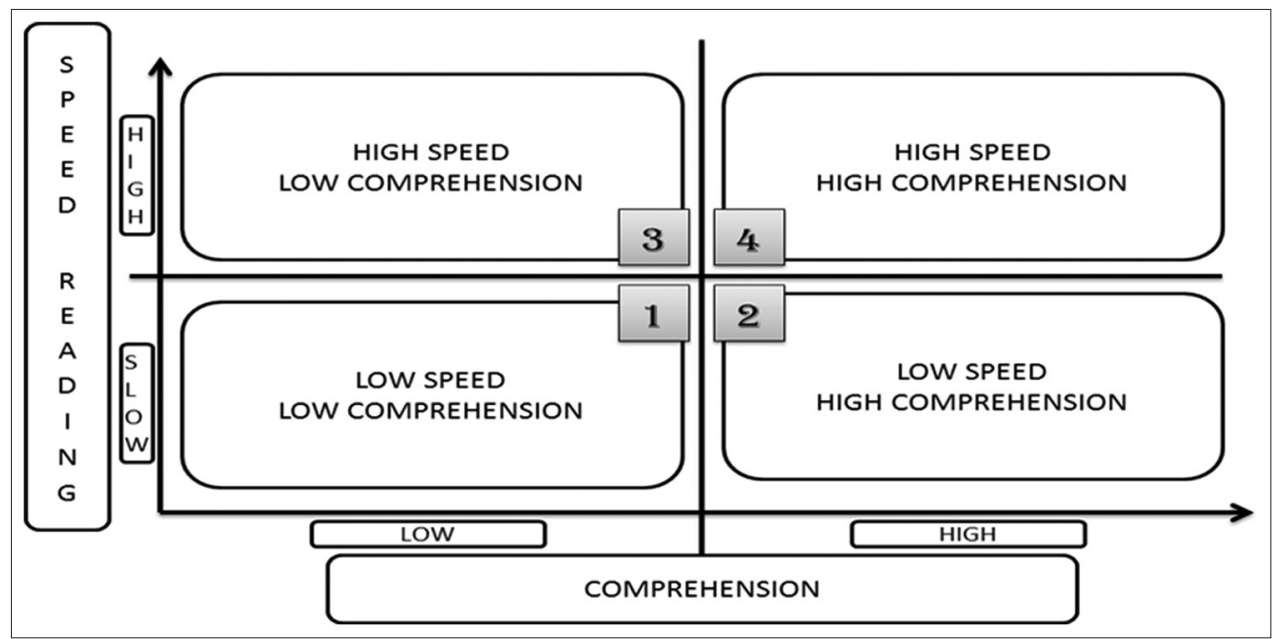

Figure 1. Readers' characteristic

reading strategies such as rate-buildup reading, skimming, and scanning in web-based portal.

\section{CONCLUSION AND SUGGESTION}

The researcher concludes that when reading activity is conducted in a purpose to comprehend, students will certainly occupy one of four slots of students' characteristics in reading as illustrate in figure 1 . Students' reading speed and comprehension are possible to be enhanced simultaneously as long as they are delivered by applying appropriate techniques with appropriate classroom exercise in appropriate method. Vocabulary mastery and collocation are two things that matter in speed reading and comprehension. Besides, text readability and level of the text also play essential role.

Through this study, the researcher has examined rate-buildup reading, skimming, and scanning strategies applied through hybrid learning method as good option for reading speed and comprehension enhancement since students of experimental group significantly boost their reading speed rate together with their comprehension. Furthermore, the researcher proposes three key points that directly contribute to students' reading speed and comprehension such as students' intellectual quotient, ability to expand and maintain eye-fixation, and range of concentration.

For further researchers who are interested in conducting web-based reading and comprehension in quasi-experimental design, it is suggested that the research is conducted in a more precise and planned ways in terms of control towards the implementation of research, especially for experimental group. In order to obtain high internal validity towards experimentation, variables that might distort the true relation, association, and/or influences the interpretation need to be carefully considered (Skelly et al., 2012, p. 9). Besides, vocabulary test should be conducted in pretest to determine whether the text given is in instructional, independent, or frustration level. To sum up, hybrid learning delivery mode is effective for reading speed and comprehension enhancement.

\section{REFERENCES}

Amir, Z., Ismail, K., \& Hussin, S. (2011). Blogs in Language Learning: Maximizing Students' Collaborative Writing. Procedia - Social and Behavioral Sciences, 18, 537543. https://doi.org/10.1016/j.sbspro.2011.05.079

Anderson, N. J. (1999). Improving Reading Speed: Activities for the classroom. English Teaching Forum, 2-5. Retrieved from http://dosfan.lib.uic.edu/usia/E-USIA/ forum/acrobat/P2.pdf

Andrews, J. W. (1952). An Approach to Speed Reading. The English Journal, 41(7), 352. https://doi. org/10.2307/808952

Arslan, R. Ş., \& Şahin-Kızıl, A. (2010). How can the use of blog software facilitate the writing process of English language learners? Computer Assisted Language Learning, 23(3), 183-197. https://doi.org/10.1080/09588221. 2010.486575

Ayres, R. (2002). Learner Attitudes Towards the Use of CALL. Computer Assisted Language Learning, 15(3), 241-249. https://doi.org/10.1076/call.15.3.241.8189

Bärenfänger, O. (2005). Learning Management: A New Approach to Structuring Hybrid Learning Arrangements. Electronic Journal of Foreign Language Teaching, 2(2), 14-35. Retrieved from http://e-flt.nus.edu.sg/v2n22005/ baerenfaenger.pdf

Baturay, M. H., Daloglu, A., \& Yildirim, S. (2010). Language practice with multimedia supported web-based grammar revision material. ReCALL, 22(03), 313-331. https://doi.org/10.1017/S0958344010000182 
Buzan. (2003). The Speed Reading Book (Revised Edition). London: BBC Worldwide Limited.

Chao, Y.-C. J., \& Lo, H.-C. (2011). Students' perceptions of Wiki-based collaborative writing for learners of English as a foreign language. Interactive Learning Environments, 19(4), 395-411. https://doi. org/10.1080/10494820903298662

Chen, C.-M., \& Huang, S.-H. (2014). Web-based reading annotation system with an attention-based self-regulated learning mechanism for promoting reading performance: Attention-based self-regulated learning mechanism. British Journal of Educational Technology, 45(5), 959-980. https://doi.org/10.1111/bjet.12119

Cutler, W. E. (1993). Triple your reading speed (Third Edition). New York: MACMILLAN.

Dogoriti, E., Pange, J., \& S. Anderson, G. (2014). The use of social networking and learning management systems in English language teaching in higher education. Campus-Wide Information Systems, 31(4), 254-263. https:// doi.org/10.1108/CWIS-11-2013-0062

Dündar, H., \& Akçayır, M. (2017). Tablet vs. paper: The effect on learners' reading performance. International Electronic Journal of Elementary Education, 4(3), IEJEE. Retrieved from https://www.iejee.com/index.php/ IEJEE/article/view/188

Dyson, M. C., \& Haselgrove, M. (2001). The influence of reading speed and line length on the effectiveness of reading from screen. International Journal of $\mathrm{Hu}$ man-Computer Studies, 54(4), 585-612. https://doi. org/10.1006/ijhc.2001.0458

Dyson, M., \& Haselgrove, M. (2000). The effects of reading speed and reading patterns on the understanding of text read from screen. Journal of Research in Reading, 23(2), 210-223. https://doi.org/10.1111/1467-9817.00115

Etxebarria, A., Garay, U., \& Romero, A. (2012). Implementation of Social Strategies in Language Learning by Means of Moodle. Journal of Language Teaching and Research, 3(2). https://doi.org/10.4304/jltr.3.2.273-282

García-Sánchez, S., \& Rojas-Lizana, S. (2012). Bridging the language and cultural gaps: the use of blogs. Technology, Pedagogy and Education, 21(3), 361-381. https:// doi.org/10.1080/1475939X.2012.719396

Gay, L., Mills, G., \& Airasian, P. (2006). Educational research: Competencies for analysis and applications. Pearson-Merrill Prentice Hall.

Gözde Girgin, E. (2011). A web 2.0 tool for language teaching with flash content. Procedia Computer Science, 3, 627-631. https://doi.org/10.1016/j.procs.2010.12.105

Grgurović, M. (2011). Blended Learning in an ESL Class: A Case Study. CALICO Journal, 29(1), 100-117. Retrieved from http://www.jstor.org/stable/calicojournal, 29(1), 100

Ho, G. A. L. (2013). Use of Social Media to Foster an Active Construction of Understanding through Cultural Reflection in a Foreign Language. Electronic Journal of Foreign Language Teaching, 10(1), 309-320.

Hsu, L., \& Sheu, C.-M. (2017). A Study of Low English Proficiency Students' Attitude toward Online Learning.
Huang, H. (2013). From web-based readers to voice bloggers: EFL learners' perspectives. Computer Assisted Language Learning, 28(2), 145-170. https://doi.org/10 $.1080 / 09588221.2013 .803983$

Hung, S.-T. A., \& Huang, H.-T. D. (2015). Blogs as a learning and assessment instrument for English-speaking performance. Interactive Learning Environments, 24(8), 1881-1894. https://doi.org/10.1080/10494820.2015.10 57746

Kessler, G., \& Bikowski, D. (2010). Developing collaborative autonomous learning abilities in computer mediated language learning: attention to meaning among students in wiki space. Computer Assisted Language Learning, 23(1), 41-58. https://doi. org/10.1080/09588220903467335

Konstant, T. (2010). Work Smarter with Speed Reading. London. Retrieved from www.teachyourself.com

Laire, D., Casteleyn, J., \& Mottart, A. (2012). Social Media's Learning Outcomes within Writing Instruction in the EFL Classroom: Exploring, Implementing and Analyzing Storify. Procedia - Social and Behavioral Sciences, 69, 442-448. https://doi.org/10.1016/j.sbspro.2012.11.432

Li, M., \& Zhu, W. (2013). Patterns of computer-mediated interaction in small writing groups using wikis. Computer Assisted Language Learning, 26(1), 61-82. https://doi. org/10.1080/09588221.2011.631142

Mahmoudi, E., Samad, A. bt A., \& Razak, N. Z. B. A. (2012). Attitude and Students' Performance in Computer Assisted English Language Learning (CAELL) for Learning Vocabulary. Procedia - Social and Behavioral Sciences, 66, 489-498. https://doi.org/10.1016/j.sbspro.2012.11.293

Margolin, S. J., Driscoll, C., Toland, M. J., \& Kegler, J. L. (2013). E-readers, Computer Screens, or Paper: Does Reading Comprehension Change Across Media Platforms?: E-readers and comprehension. Applied Cognitive Psychology, 27(4), 512-519. https://doi. org/10.1002/acp.2930

Noni, N. (2004). The Use of Computer Assisted Language Learning (CALL) to Improve Students English Achievement based on Modes of Teaching Delivery. Jurnal Pendidikan Dan Pembelajaran, 16(2), 101-106. Retrieved from http://journal.um.ac.id/index.php/pendidikan-dan-pembelajaran/article/viewArticle/2765

O’Reilly, R. P., \& Walker, J. E. (1989). An analysis of reading rates in college students. Reading Research and Instruction, 29(2), 1-11. https://doi. org/10.1080/19388079009558001

Özdemir, E. (2017). Promoting EFL learners' intercultural communication effectiveness: a focus on Facebook. Computer Assisted Language Learning, 30(6), 510-528. https://doi.org/10.1080/09588221.2017.1325907

Rose, E. (2011). The phenomenology of on-screen reading: University students' lived experience of digitised text: Phenomenology of on-screen reading. British Journal of Educational Technology, 42(3), 515-526. https://doi. org/10.1111/j.1467-8535.2009.01043.x 
Saglam, A. L. G., \& Sert, S. (2012). Perceptions of In-Service Teachers Regarding Technology Integrated English Language Teaching. Turkish Online Journal of Qualitative Inquiry, 3(3), 1-14. https://doi.org/10.17569/tojqi.55006

Skelly, A., Dettori, J., \& Brodt, E. (2012). Assessing bias: the importance of considering confounding. Evidence-Based Spine-Care Journal, 3(01), 9-12. https:// doi.org/10.1055/s-0031-1298595

Snow, C. E. (2002). Reading for understanding: toward a research and development program in reading comprehension (p. 156). RAND. Retrieved from ttp://www.rand.org

Sun, Y.-C., \& Yang, F.-Y. (2013). I help, therefore, I learn: service learning on Web 2.0 in an EFL speaking class. Computer Assisted Language Learning, 28(3), 202-219. https://doi.org/10.1080/09588221.2013.818555

Suthiwartnarueput, T., \& Wasanasomsithi, P. (2012). Effects of Using Facebook as a Medium for Discussions of English Grammar and Writing of Low-Intermediate EFL Students. Electronic Journal of Foreign Language Teaching, 9(2), 194-214.

Thielen, J., Grochowski, P., \& Perpich, D. (2016). Read Smarter, Not Faster: Reflections on a Speed Reading and Reading Retention Workshop for Engineering Graduate Students. Science \& Technology Libraries, 35(4), 313337. https://doi.org/10.1080/0194262X.2016.1244503

Tran, T. N. Y., \& Nation, P. (2014). Reading Speed Improvement in a Speed Reading Courseand Its Effect on Language Memory Span. Electronic Journal of Foreign Language Teaching, 11(1), 5-20. Retrieved from http:// e-flt.nus.edu.sg/v11n12014/tran.pdf
Tselios, N., Daskalakis, S., \& Papadopoulou, M. (2011). Assessing the Acceptance of a Blended Learning University Course. Educational Technology \& Society, 14(2), 224-235. Retrieved from http://www.ifets.info/journals/14_2/19.pdf

Vurdien, R. (2013). Enhancing writing skills through blogging in an advanced English as a Foreign Language class in Spain. Computer Assisted Language Learning, 26(2), 126-143. https://doi.org/10.1080/09588221.2011 .639784

Wainwright, G. (2007). How to read faster and recall more (Third Edition). Begbroke, Oxford: How To Books Ltd.

Weber, D. (2002). Methods and apparata for enhancing text to increase reading speed and comprehension. Google Patents. Retrieved from https://www.google.com/patents/US20020124026

Yakut, A. D., \& Aydın, S. (2015). An experimental study on the effects of the use of blogs on EFL reading comprehension. Innovation in Language Learning and Teaching, 11(1), 1-16. https://doi.org/10.1080/17501229.201 5.1006634

Yeou, M. (2016). An Investigation of Students' Acceptance of Moodle in a Blended Learning Setting Using Technology Acceptance Model. Journal of Educational Technology Systems, 44(3), 300-318. https://doi. org/10.1177/0047239515618464

Zou, B., Wang, D., \& Xing, M. (2015). Collaborative tasks in Wiki-based environment in EFL learning. Computer Assisted Language Learning, 29(5), 1001-1018. https:// doi.org/10.1080/09588221.2015.1121878 